\title{
Conversion of Functional Synapses into Silent Synapses in the Trigeminal Brainstem after Neonatal Peripheral Nerve Transection
}

\author{
Fu-Sun Lo and Reha S. Erzurumlu \\ Department of Anatomy and Neurobiology, University of Maryland School of Medicine, Baltimore, Maryland 21201
}

\begin{abstract}
One of the major consequences of neonatal infraorbital nerve damage is irreversible morphological reorganization in the principal sensory nucleus $(\mathrm{PrV})$ of the trigeminal nerve in the brainstem. We used the voltage-clamp technique to study synaptic transmission in the normal and the denervated PrV of neonatal rats in an in vitro brainstem preparation. Most of the synapses in the PrV are already functional at birth. Three days after peripheral deafferentation, functional synapses become silent, lacking AMPA receptor-mediated currents. Without sensory inputs from the whiskers, silent synapses persist through the second postnatal week, indicating that the maintenance of AMPA receptor function depends on sensory inputs. High-frequency $(50 \mathrm{~Hz})$ electrical stimulation of the afferent pathway, which mimics sensory input, restores synaptic function, whereas low-frequency $(1 \mathrm{~Hz})$ stimulation has no effect. Application of glycine, which promotes AMPA receptor exocytosis, also restores synaptic function. Therefore, normal synaptic function in the developing PrV requires incoming activity via sensory afferents and/or enhanced AMPA receptor exocytosis. Sensory deprivation most likely results in AMPA receptor endocytosis and/or lateral diffusion to the extrasynaptic membrane.
\end{abstract}

Key words: synaptic plasticity; AMPA receptors; NMDA receptors; principal sensory nucleus; infraorbital nerve; barrelettes

\section{Introduction}

In the trigeminal principal sensory nucleus $(\mathrm{PrV})$ of rodents, whisker-specific afferent arbors and postsynaptic elements form neural modules ("barrelettes"), each representing a single whisker or sinus hair on the snout. Three classes of morphologically and physiologically distinguishable neurons reside in the rat PrV: barrelette cells, interbarrelette cells, and GABAergic inhibitory interneurons (Arends and Jacquin, 1993; Lo et al., 1999). Deprivation of sensory afferents by infraorbital (IO) nerve transection at birth results in irreversible disruption of the barrelettes and neural patterning in the upstream thalamic and cortical targets (for review, see Woolsey, 1990). Loss of presynaptic terminal patterns is accompanied by symmetrical differentiation of barrelette cell dendrites (Lo and Erzurumlu, 2001). Despite these significant morphological changes, membrane properties of barrelette cells do not change (Lo and Erzurumlu, 2001). Effects of neonatal and adult peripheral nerve damage on the morphological and functional organization of central relay stations have been widely studied in the rodent trigeminal system. But the mechanisms underlying synaptic plasticity and reorganization are not fully understood.

Most forms of synaptic plasticity require calcium influx through NMDA receptors (for review, see Bear and Malenka

Received Dec. 11, 2006; revised April 4, 2007; accepted April 9, 2007.

This work was supported by National Institutes of Health Grant NS037070.

Correspondence should be addressed to Dr. Reha S. Erzurumlu, Department of Anatomy and Neurobiology, University of Maryland, School of Medicine, 20 Penn Street, Health Science Facility II S251, Baltimore, MD 21201. E-mail: rerzu001@umaryland.edu.

DOI:10.1523/JNEUROSCI.5342-06.2007

Copyright $\odot 2007$ Society for Neuroscience $\quad$ 0270-6474/07/274929-06\$15.00/0
1994; Malenka and Bear 2004). Pharmacological blockade of NMDA receptors prevents the induction of long-term potentiation (LTP) and long-term depression (LTD), which are believed to underlie selective synaptic stabilization and elimination, respectively (Scheetz and Constantine-Paton, 1994). Both LTP and LTD are expressed via postsynaptic AMPA receptor trafficking (for review, see Malinow and Malenka 2002; Bredt and Nicoll 2003; Sheng and Lee 2003). In the present study, we focused on the barrelette cells that mainly project to the contralateral thalamus. We used a minimal stimulation technique to test the function of AMPA and NMDA receptors at different holding potentials (Isaac et al., 1995; Liao et al., 1995) in normal and denervated barrelette neurons. We found that the majority of synapses are already mature at birth in the normal PrV. However, IO nerve transection at birth rapidly diminishes functional AMPA receptors but leaves NMDA receptors intact. Consequently, synapses become silent at resting membrane potential. High-frequency $(50 \mathrm{~Hz})$ stimulation of the afferent pathway and application of glycine, which promotes AMPA receptor exocytosis, restores AMPA receptor function. Collectively, these findings suggest that sensory activity plays a critical role in the acquisition and stabilization of functional AMPA receptors in the developing PrV. Rapid conversion of silent synapses into functional synapses after artificial stimulation of the denervated pathway opens up possibilities for management of peripheral nerve injury-induced synaptic plasticity in the CNS.

\section{Materials and Methods}

IO nerve transection. Postnatal day 0 ( $\mathrm{P} 0)$ Sprague Dawley rat pups were anesthetized by hypothermia. The IO nerve on the right side was cut with sterile microscissors. All animal experimentation protocols followed the 
National Institutes of Health guidelines and were approved by the University of Maryland, Baltimore Institutional Animal Care and Use Committee.

Brain slice preparation. We obtained brainstem slices from normal rat pups (P0- P13) and IO nerve-transected pups (P4-P13). The animals were killed with halothane (Halocarbon Laboratory, River Edge, $\mathrm{NJ}$ ), and the brains were removed and immersed in cold $\left(4^{\circ} \mathrm{C}\right)$ sucrose-based artificial CSF (ACSF) containing the following (in mM): 234 sucrose, 2.5 $\mathrm{KCl}, 1.25 \mathrm{NaH}_{2} \mathrm{PO}_{4}, 10 \mathrm{MgSO}_{4}, 24 \mathrm{NaHCO}_{3}, 11$ glucose, $0.5 \mathrm{CaCl}_{2}$, bubbled with $95 \% \mathrm{O}_{2}$ and $5 \% \mathrm{CO}_{2}, \mathrm{pH}$ 7.4. The brainstem was then embedded in $2 \%$ agar and cut into $400-\mu \mathrm{m}$-thick transverse sections with a Vibratome (Electron Microscopy Sciences, Hatfield, PA) into sucrose-based ACSF at $4^{\circ} \mathrm{C}$. Slices containing the PrV were selected under a dissecting microscope. The normal (control) side of each slice was marked. After $1 \mathrm{~h}$ incubation in normal ACSF [containing the following (in mM): $124 \mathrm{NaCl}, 2.5 \mathrm{KCl}, 1.25 \mathrm{NaH}_{2} \mathrm{PO}_{4}, 2 \mathrm{MgSO}_{4}, 26 \mathrm{NaHCO}_{3}, 10$ glucose, $\left.2 \mathrm{CaCl}_{2}, \mathrm{pH} 7.4\right]$ at room temperature, each slice was transferred into a submerged-type recording chamber (Fine Science Tools, North Vancouver, British Columbia, Canada) and continuously perfused $(>2$ $\mathrm{ml} / \mathrm{min}$ ) with normal ACSF at room temperature. During electrophysiological recording, 50-100 $\mu \mathrm{m}$ picrotoxin was added into the ACSF to block GABAergic responses. All chemicals referred to above and in the following sections were purchased from Sigma (St. Louis, MO).

Electrophysiology. Whole-cell patch micropipettes were pulled horizontally in three stages from borosilicate glass (K150F-4; World Precision Instruments, Sarasota, FL) with a P-87 puller (Sutter Instrument, Novato, CA). The patch electrodes were backfilled with a Cs-based intracellular solution [containing the following (in mM): $115 \mathrm{CsMeSO}_{3}, 10$ $\mathrm{NaCl}, 1 \mathrm{KCl}, 4 \mathrm{MgCl}_{2}, 1 \mathrm{CaCl}_{2}, 11$ EGTA, 20 HEPES, $3 \mathrm{Na}_{2}$-ATP, 0.5 $\mathrm{Na}_{2}$-GTP, 0.1 spermine, $\mathrm{pH} 7.25,>290 \mathrm{mOsm}$ ] with a tip resistance of 7-10 M $\Omega$. For tetanic stimulation experiments, EGTA was reduced to 0.4 $\mathrm{mm}$, and $\mathrm{CaCl}_{2}$ was omitted in the intracellular solution. Barrelette cells were blindly patched as described previously (Lo et al., 1999). These cells were identified by their prominent transient $\mathrm{K}^{+}\left(I_{\mathrm{A}}\right)$ conductance (Lo et al., 1999), which was gradually blocked by $\mathrm{Cs}^{+}$dialyzed from the micropipette $3 \mathrm{~min}$ after whole-cell recording. Recorded neurons were voltage-clamped at either -70 or $+60 \mathrm{mV}$. A pair of fine-tip stimulating electrodes (0.5 M $\Omega$, IRM33A05KT; World Precision Instruments) was inserted at various points along the trigeminal tract $(\mathrm{TrV})$, lateral to the ventral $\mathrm{PrV}$ (barrelette region). Electrical pulses (0.2-0.3 ms duration; 0.05-0.2 mA) were passed through the electrodes to evoke EPSCs. All physiological data were collected with an Instrutech (Port Washington, NY) ITC-16 interface unit and stored on a Pentium III personal computer with Pulses (HEKA) software program (Instrutech).

Test for silent synapses. Barrelette neurons were first voltage-clamped at $+60 \mathrm{mV}$. The TrV was stimulated by 60 pulses at $0.2 \mathrm{~Hz}$. Stimulus intensity was adjusted to around threshold, so that some trials failed to evoke EPSCs. Then the neurons were clamped at $-70 \mathrm{mV}$ to determine changes in failure rate between the two membrane potentials. The amplitude of EPSCs at $+60 \mathrm{mV}$ was measured at $30 \mathrm{~ms}$ after stimulus, when NMDA receptor-mediated EPSCs reach the peak. The amplitude of EPSCs at $-70 \mathrm{mV}$ was measured $8 \mathrm{~ms}$ after stimulus (the peak of AMPA receptormediated EPSCs). A peak amplitude of less than two times noise SD was designated as failure of synaptic transmission. Pharmacological studies verified the reliability of this timing measurement. Figure $1 a, b$ shows an example of a functional synapse. Application of NBQX (1,2,3,4tetrahydro-6-nitro-2,3-dioxo-benzo quinoxaline-7-sulfonamide disodium; $10 \mu \mathrm{M}$ ), an AMPA receptor antagonist, only blocked the EPSCs at $-70 \mathrm{mV}$ (Fig. 1, compare $c, d$ ). This also indicated that silent synapses resulted from loss of AMPA receptors.

Tetanic stimulation of the afferent pathway. In this set of experiments, patch electrodes were filled with low EGTA concentration to reduce chelating intracellular $\mathrm{Ca}^{2+}$. When the barrelette neuron showed higher failure rate of AMPA receptor-mediated EPSCs at $-70 \mathrm{mV}$, the neuron was clamped to $-10 \mathrm{mV}$. Then, we applied six trains ( $1 \mathrm{~s}$ duration) of 50 $\mathrm{Hz}$ stimuli of suprathreshold intensity at $30 \mathrm{~s}$ intervals, or $1 \mathrm{~Hz}$ of 100 or 300 stimuli to the $\mathrm{TrV}$. After this, the neuron was clamped to $-70 \mathrm{mV}$ again and tested by minimal stimulation for $>40 \mathrm{~min}$.

Glycine application experiments. In a separate set of experiments, when

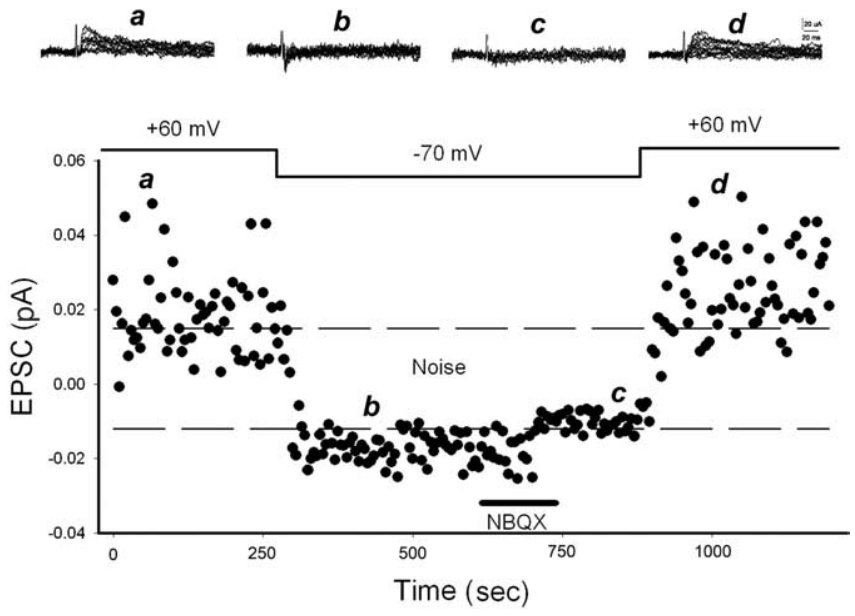

Figure 1. Blockade of AMPA receptors switches functional synapses into silent ones. An example of functional synapse with NMDA receptor-mediated EPSCs at $+60 \mathrm{mV}$ and AMPA receptor-mediated EPSCs at $-70 \mathrm{mV}$. Insets $\boldsymbol{a}$ and $\boldsymbol{b}$ are records at points $\boldsymbol{a}$ and $\boldsymbol{b}$, respectively. $\boldsymbol{c}, \boldsymbol{d}$, Application of NBQX specifically blocks the EPSCs at $-70 \mathrm{mV}$ (c) and leaves EPSCs at +60 $\mathrm{mV}(\boldsymbol{d})$ intact, indicating that silent synapses result from a loss of AMPA receptor function. The dashed lines denote noise level determined by two times the noise SD here and in all figures.

the barrelette neuron showed silent synapses, the neuron was clamped at $-70 \mathrm{mV}$, and glycine $(200 \mu \mathrm{M})$ was bath applied for $10 \mathrm{~min}$. The AMPA receptor-mediated EPSCs at $-70 \mathrm{mV}$ were tested by minimal stimulation at $0.2 \mathrm{~Hz}$ during and $>40 \mathrm{~min}$ after glycine application. The extracellular $\mathrm{Mg}^{2+}$ concentration is important for blocking NMDA receptors. We used $2 \mathrm{mM} \mathrm{Mg}^{2+}$ in this study. Even at a holding potential of -70 $\mathrm{mV}$, a residual NMDA receptor-mediated EPSC induced by maximal stimulation of $\operatorname{TrV}$ is still present in the denervated $\operatorname{PrV}$ (data not shown). The increase of AMPA receptor insertion by glycine is most likely mediated by activation of NMDA receptors in the PrV, as reported by Lu et al. (2001). The mechanisms underlying the glycine effect awaits further experimentation.

Statistical analysis. All data are expressed as mean \pm SEM, and Student's $t$ test and $\chi^{2}$ test were used.

\section{Results}

We first tested postsynaptic responses of barrelette cells in normal PrV of newborn rats (P1-P3). These cells can be identified readily by their membrane properties (Lo et al., 1999). The majority of the recorded cells $(87.5 \% ; n=8)$ showed normal synaptic transmission at resting potential (Fig. $2 \mathrm{~A}$ ), namely the minimal stimulation induced EPSCs at both +60 and $-70 \mathrm{mV}$ with similar failure rates. Only $12.5 \%$ of recorded cells exhibited silent synapses with a much higher failure rate at $-70 \mathrm{mV}$ than that at $+60 \mathrm{mV}$. The proportion of silent synapses $(14.3 \% ; n=14)$ remained unaltered ( $\chi^{2}$ test; $\left.p>0.05\right)$ on $\mathrm{P} 4-\mathrm{P} 13$. We divided the rat pups into two age groups: the first postnatal week (P1-P6) and the second postnatal week (P7-P13). In the first postnatal week, $80 \%$ of barrelette cells $(n=10)$ showed functional synapses (Fig. $2 B$ ). In the second postnatal week, $92 \%$ of cells $\left(n=12 ; \chi^{2}\right.$ test; $p>0.05$ ) had functional synapses (Fig. $2 C, D$ ). Based on these findings, we concluded that most of the barrelette cells have functionally mature synapses at birth in the PrV.

To test the effects of long-term deprivation on synaptic function, we recorded from barrelette cells in deafferented PrV on P4-P13 (i.e., 3-10 d after IO nerve transection). In the first postnatal week (P4-P6), the vast majority of cells $(92.9 \% ; n=14)$ exhibited silent synapses (Fig. $2 E, F$ ) with a $50 \pm 6 \%$ increase in failure rate at -70 $\mathrm{mV}$ than that at $+60 \mathrm{mV}$. The noticeably high proportion of silent synapses was in sharp contrast to that of normal PrV $\left(20 \%\right.$; $\chi^{2}$ test; $p<0.01)$. Thus, long-term deprivation diminished AMPA receptor- 
A
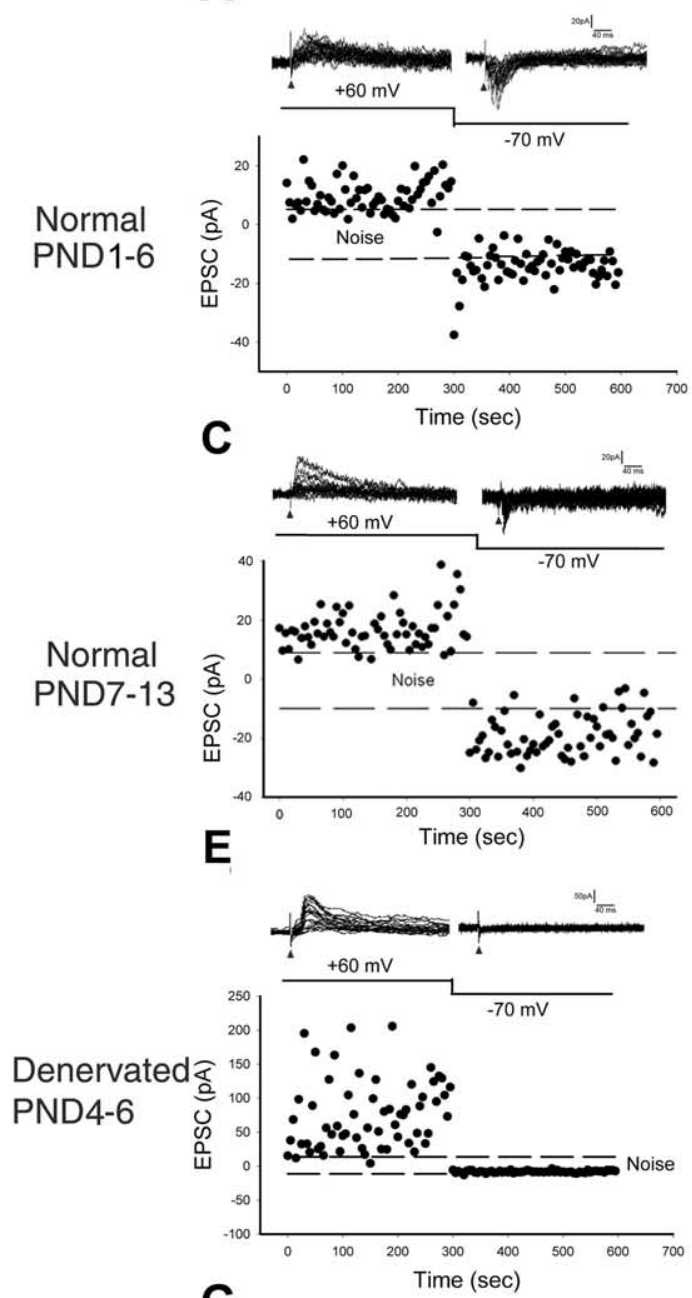

G

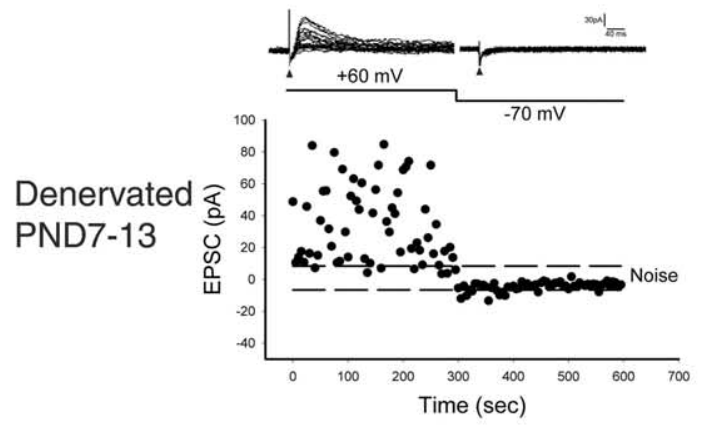

B

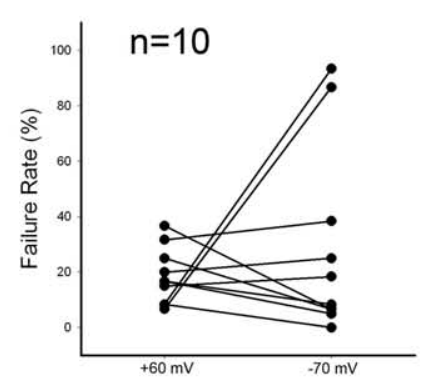

D

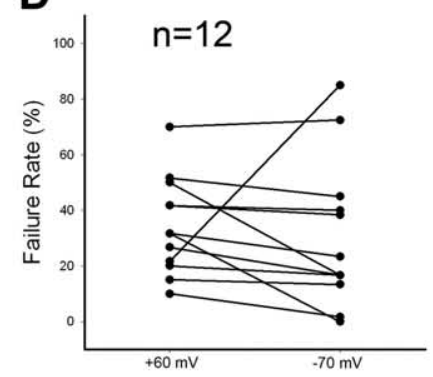

$\mathbf{F}$

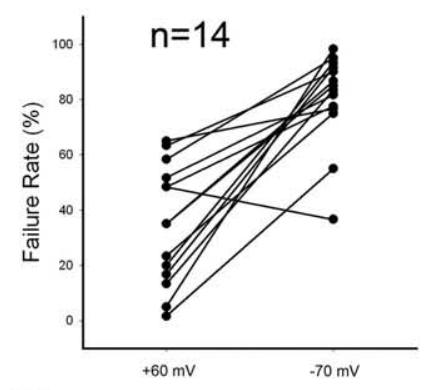

$\mathbf{H}$

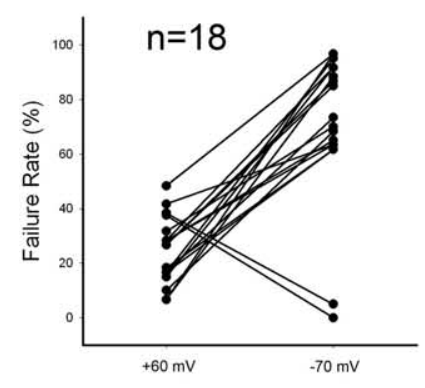

Figure 2. Long-term deprivation converts functional synapses into silent ones. $A, C$, Examples of functional synapses in barrelette cells of normal PrV in the first and second postnatal week separately. Note that minimal stimulation of TrV induced EPSCs at both +60 and $-70 \mathrm{mV}$ with similar failure rate. $\boldsymbol{B}, \boldsymbol{D}$, The majority of cells in both postnatal weeks showed similar failure rates at different holding potentials. $\boldsymbol{E}, \mathbf{G}$, Examples of silent synapses in both postnatal weeks. Note that minimal stimulation failed to induce EPSCs at $-70 \mathrm{mV}$. $\boldsymbol{F}, \boldsymbol{H}$, Most of the cells in the deprived PrV exhibited higher failure rates at $-70 \mathrm{mV}$ than those at $+60 \mathrm{mV}$.

mediated postsynaptic responses and left NMDA receptor function intact, subsequently switching functional synapses into silent ones. In the second postnatal week, a similar proportion $(88.9 \% ; n=18$; $\chi^{2}$ test; $\left.p>0.05\right)$ of cells exhibited silent synapses with similar failure rate difference ( $55.8 \pm 5 \%$; $t$ test; $p>0.4$ ) between -70 and $+60 \mathrm{mV}$ $(t$ test; $p>0.4$ ) (Fig. $2 G, H$ ). Hence, silent synapses persist in the absence of functional sensory afferent inputs. Interestingly, long- term deprivation did not affect postsynaptic NMDA receptor function.

In the PrV, barrelette cells receive inputs from whisker-specific trigeminal ganglion cells, which show either lowfrequency spontaneous or high-frequency sensory activities (Minnery and Simon, 2003; Shoykhet et al., 2003). If silent synapses are a consequence of the absence of high-frequency sensory inputs, then highfrequency electrical stimulation of the afferent pathway could convert silent synapses into functional synapses. We tested this possibility by pairing depolarization $(-10 \mathrm{mV})$ and 300 stimuli at $50 \mathrm{~Hz}$ applied to the $\mathrm{TrV}$. After the pairing stimulation, silent synapses immediately converted into functional ones in all tested neurons $(n=6)$ (Fig. $3 A, B)$. The averaged failure rate at $-70 \mathrm{mV}$ dropped from $73 \pm$ 12 to $33 \pm 11 \%(t$ test; $p<0.05)$, and the effect lasted only 15-30 min. This effect may be because of the fact that the PrV had been deprived of sensory afferents for $>3$ d. In the normal PrV (Guido et al., 2001) and superior colliculus (Lo and Mize, 2001), the same stimulus strategy induces long-term plasticity. This short-term effect was frequency-dependent; depolarization $(-10 \mathrm{mV})$ plus $1 \mathrm{~Hz}$ with $100(n=2)$ or $300(n=4)$ stimuli had no effect (Fig. $3 C, D)$. The averaged failure rates at -70 $\mathrm{mV}$ were not significantly different $(t$ test; $p>0.7)$. Thus, it appears that the acquisition and stabilization of functional AMPA receptors require high-frequency sensory afferent activity.

Silent synapses may be attributed to the absence of AMPA receptors during early development or endocytosis of AMPA receptors. Previously, endocytosis of AMPA receptors was shown to be induced by either low-frequency stimulation or pharmacological manipulations (Malinow and Malenka, 2002; Bredt and Nicoll, 2003; Sheng and Lee, 2003; Ashby et al., 2004). Here, we provide a novel model of silent synapses, which allows us to test whether AMPA receptor exocytosis switches silent synapses into functional ones. Application of glycine $(200 \mu \mathrm{M} ; 10 \mathrm{~min})$, which promotes AMPA receptor exocytosis through activation of NMDA receptors (Lu et al., 2001), did in fact switch silent synapses into functional ones in all tested neurons $(n=4)$ (Fig. $3 E, F)$. On average, the failure rate at $-70 \mathrm{mV}$ significantly $(t$ test; $p<0.001)$ decreased by $44 \pm$ $6 \%$ after glycine application. Therefore, long-term deprivation results in loss of functional AMPA receptors.

\section{Discussion}

Our results show that neonatal peripheral sensory nerve injury dramatically alters synaptic maturation and leads to "silent" syn- 
apses in the first relay station of the trigeminal pathway in the brain. High-frequency stimulation that mimics sensory afferent activity immediately switches silent synapses into functional synapses. We hypothesize that the maturation and stabilization of functional synapses in the CNS require high-frequency inputs that come through the sensory afferents during the critical period. To our knowledge, central correlates of peripheral nerve injury have not been studied at the synaptic level. It remains to be tested whether artificial stimulation of the sensory nerve roots can alleviate peripheral nerve injury-induced synaptic plasticity in the CNS. Our findings can be coupled with research on neural prosthetics and brain-machine interfaces (for review, see Donoghue, 2002; Lebedev and Nicolelis, 2006). So far, research on neural prosthetics has largely focused on detecting and translating neural signals into commands that can control devices. Mimicking lost sensory inputs in lower somatosensory pathways will undoubtedly be important for sensorymotor integration in the somatosensory, motor, and association cortices.

\section{Neonatal denervation-induced changes in the PrV}

IO nerve transection during $\mathrm{P} 0-\mathrm{P} 3$ in rats leads to irreversible morphological changes in the PrV as well as other brainstem trigeminal nuclei. First, afferent terminal and barrelette patterns dissolve (Belford and Killackey, 1979). This is accompanied by the loss of patterning of trigeminothalamic (barrelette) cells in the PrV (Bates et al., 1982). These morphological changes are also reflected in the organization of upstream trigeminal centers such as the ventroposteromedial nucleus of the thalamus and the barrel cortex (Killackey et al. 1976; Belford and Killackey 1979; Killackey and Belford, 1979). Despite these severe structural alterations, membrane properties of barrelette and interbarrelette neurons in the PrV do not change (Lo and Erzurumlu, 2001). Another major consequence of neonatal IO nerve transection in rats is a significant increase in cell death in the $\operatorname{PrV}$, and its projection zone in the thalamus (Arvidsson, 1979; Miller et al., 1991; Henderson et al., 1993; Miller and Kuhn, 1997; Sugimoto et al., 1999; Baldi et al., 2000). Several authors have attributed this loss of barrelette patterns to accelerated programmed cell death and provided evidence that neurotrophin treatments can rescue many cells in the trigeminal ganglion and brainstem from cell death (Henderson et al., 1993; Baldi et al., 2000). Clearly, trans-synaptic cell death is an important caveat in the interpretation of our results. Seventy-percent higher apoptotic profiles in the denervated $\operatorname{PrV}$, compared with normal developing PrV (Sugimoto et al., 1999) or a one-third reduction in the number of cells in the PrV (Miller and Kuhn, 1997), have been noted. But these studies did not address whether the cell loss is selective for any or all three classes of neurons in the PrV. Previously, we showed that neonatal IO nerve transection does not alter membrane properties of barrelette or interbarrelette neurons, and we noted that IPSPs mediated by GABAergic neurons are still present (Lo and Erzurumlu, 2001, 2002). In addition, barrelette and interbarrelette neurons can be identified morphologically (and GABAergic neurons immunohistochemically) in the denervated PrV. Thus, despite a pronounced increase in the developmentally regulated apoptosis, many $\operatorname{PrV}$ neurons of all three classes survive and maintain their electrophysiological and morphological characteristics. Our present results show that another major consequence of critical period denervation of the $\mathrm{PrV}$ is conversion of functional synapses into silent synapses. This form of synaptic plasticity is clearly activity dependent, because high-frequency stimulation of the $\mathrm{TrV}$, which mimics the sensory activity carried along the IO nerve, can rapidly convert silent synapses into functional ones.

\section{Physiological evidence for activity-dependent plasticity in the PrV}

The role of neural activity in patterning and plasticity of barrelette patterns in the rodent PrV have been debated. Pioneering studies showed that tetrodotoxin (TTX) and local anesthetic bupivacaine application on the IO nerve did not affect barrelette formation in the rat $\operatorname{PrV}$ (Henderson et al., 1992). More recent 
studies uncovered that trigeminal ganglion cells have TTXresistant $\mathrm{Na}^{+}$and voltage-dependent $\mathrm{Ca}^{2+}$ channels that produce $\mathrm{Ca}^{2+}$ spikes (Kim and Chung, 1999; Cabanes et al., 2002). Furthermore, TTX or bupivacaine does not appear to block spontaneous activity of trigeminal ganglion cells (Minnery et al., 2003; Shoykhet et al., 2003). In contrast to pharmacological activity blockade experiments, gene deletion or alteration studies in mice showed that disruption of NMDA receptor subunits NR1 or NR2B prevent development of barrelette patterns altogether ( $\mathrm{Li}$ et al., 1994; Kutsuwada et al., 1996; Iwasato et al., 1997). This provides strong support for the role of activity in neural patterning.

Our recent results also show that the morphological changes in the PrV of NR1 knock-out or knock-down mice are similar to those in deprived PrV (Lee et al., 2005). This suggests that the $\mathrm{Ca}^{2+}$ influx through NMDA receptors plays a pivotal role in synaptic plasticity in the PrV. In NR1 knock-out or knock-down mice, the lack of NMDA receptors reduces the $\mathrm{Ca}^{2+}$ influx. Whereas, in deprived $\operatorname{PrV}$, although NMDA receptors are present, the lack of AMPA receptor-mediated response restricts $\mathrm{Ca}^{2+}$ influx through NMDA receptors. Thus, attenuation of either NMDA receptor or AMPA receptor activation results in similar morphological changes. Most of the earlier studies are based on morphological observations. The present study provides physiological evidence that shows that the acquisition and stabilization of functional synapses require high-frequency impulses from whiskerspecific sensory afferents. NMDA receptor surface expression might be either activity independent or dependent on low-frequency spontaneous activity. Regardless of the scenario, the present results indicate that normal synaptic function in the developing $\operatorname{PrV}$ depends on high-frequency sensory afferent inputs.

It is possible that impaired NMDAR function and IO nerve transection lead to another common pathway in augmenting apoptosis in the trigeminal brainstem and upstream centers (Arvidsson, 1979; Miller et al., 1991; Waite et al., 1992; Henderson et al., 1993; Miller and Kuhn, 1997; Sugimoto et al., 1999; Baldi et al., 2000; de Rivero Vaccari et al., 2006). Although molecular mechanisms that tie these two events to apoptosis are not known, there is strong evidence to support the idea that calcium signaling through the NMDARs is essential in the patterning of the trigeminal pathway. A single amino acid residue in the NR1 subunit (N598) is critical for $\mathrm{Ca}^{2+}$ influx and $\mathrm{Mg}^{2+}$ block associated with NMDARs (Sakurada et al., 1993; Kashiwagi et al., 1997; Schneggenburger and Ascher, 1997; Zheng et al., 1999). Single et al. (2000) generated mice that expressed mutant NMDARs by substituting asparagine $(\mathrm{N})$ with glutamine $(\mathrm{Q})$ or arginine (R). Animals with these point mutations died shortly after birth and displayed similar phenotypes to that of NR1 knock-out mice. The phenotype was partially rescued in heterozygous mice that expressed both wild-type and mutant NR1 subunits. Barrels formed in heterozygous mice with $\geq 25 \%$ of pure wild-type NMDARs, results quite similar to our observations from NR1 knock-down mice. More recently, Rudhard et al., (2003) used the asparagine (N) to arginine (R) point mutation in N598. This mutation abolished the $\mathrm{Mg}^{2+}$ block and $\mathrm{Ca}^{2+}$ permeability and impaired the coincidence detection properties of NMDARs. NR1 N598R mutant mice also failed to develop barrelette patterns in the brainstem trigeminal nuclei (Rudhard et al., 2003).

\section{Effect of sensory inputs on AMPA receptor trafficking}

Long-term $(>3 \mathrm{~d})$ sensory deprivation created by peripheral nerve transection switches functional synapses into silent ones by diminishing postsynaptic functional AMPA receptors. This physiological result might be resulting from AMPA receptor endocytosis and/or lateral diffusion to extrasynaptic membrane (for reviews, see Triller and Choquet, 2005; Groc et al., 2006). Highfrequency synaptic inputs $(50 \mathrm{~Hz} ; 300$ pulses) temporarily restore AMPA receptor function in the deprived PrV. In nondeprived preparations, the high-frequency tetanus induces LTP (Guido et al., 2001; Lo and Mize, 2001), which suggests that stabilization of AMPA receptors requires persistent sensory inputs. Our findings agree with the observations derived from the visual system. Visual experience rapidly causes LTP, especially of AMPA receptormediated current, and promotes functional synaptic refinement (Zhang et al. 2000; Zhou et al. 2003; Lu and Constantine-Paton, 2004). Therefore, it may be a common mechanism across different sensory systems that afferent inputs from the sense organs promote AMPA receptor exocytosis, stabilization, and lateral diffusion into postsynaptic membrane in developing synapses.

\section{References}

Arends JJ, Jacquin MF (1993) Lucifer Yellow staining in fixed brain slices: optimal methods and compatibility with somatotopic markers in neonatal brain. J Neurosci Methods 50:321-339.

Arvidsson J (1979) An ultrastructural study of transganglionic degeneration in the main sensory trigeminal nucleus of the rat. J Neurocytol 8:31-45.

Ashby MC, De La Rue SA, Ralph GS, Uney J, Collingridge GL, Henley JM (2004) Removal of AMPA receptors (AMPARs) from synapses is preceded by transient endocytosis of extrasynaptic AMPARs. J Neurosci 24:5172-5176.

Baldi A, Calia E, Ciampini A, Riccio M, Vetuschi A, Persico AM, Keller F (2000) Deafferentation-induced apoptosis of neurons in thalamic somatosensory nuclei of the newborn rat: critical period and rescue from cell death by peripherally applied neurotrophins. Eur J Neurosci 12:2281-2290.

Bates CA, Erzurumlu RS, Killackey HP (1982) Central correlates of peripheral pattern alterations in the trigeminal system of the rat. III. Neurons of the principal sensory nucleus. Brain Res 281:108-113.

Bear MF, Malenka RC (1994) Synaptic plasticity: LTP and LTD. Curr Opin Neurobiol 4:389-399.

Belford GR, Killackey HP (1979) The development of vibrissae representation in subcortical trigeminal centers of the neonatal rat. J Comp Neurol 188:63-74.

Bredt DS, Nicoll RA (2003) AMPA receptor trafficking at excitatory synapses. Neuron 40:361-379.

Cabanes C, López de Armentia M, Viana F, Belmonte C (2002) Postnatal changes in membrane properties of mice trigeminal ganglion neurons. J Neurophysiol 87:2398-2407.

de Rivero Vaccari JC, Casey GP, Aleem S, Park WM, Corriveau RA. (2006) NMDA receptors promote survival in somatosensory relay nuclei by inhibiting Bax-dependent developmental cell death. Proc Natl Acad Sci USA 103:16971-16976.

Donoghue JP. (2002) Connecting cortex to machines: recent advances in brain interfaces. Nat Neurosci 5 Suppl:1085-1088.

Groc L, Gustafsson B, Hanse E (2006) AMPA signaling in nascent glutamatergic synapses: there and not there! Trends Neurosci 29:132-139.

Guido W, Lo F-S, Erzurumlu RS (2001) Synaptic plasticity in the trigeminal principal nucleus during the period of barrelette formation and consolidation. Dev Brain Res 132:97-102.

Henderson TA, Woolsey TA, Jacquin MF (1992) Infraorbital nerve blockade from birth does not disrupt central trigeminal pattern formation in the rat. Dev Brain Res 66:146-152.

Henderson TA, Rhoades RW, Bennett-Clarke CA, Osborne PA, Johnson EM, Jacquin MF (1993) NGF augmentation rescues trigeminal ganglion and principalis neurons, but not brainstem or cortical whisker patterns, after infraorbital nerve injury at birth. J Comp Neurol 336:243-260.

Isaac JT, Nicoll RA, Malenka RC (1995) Evidence for silent synapses: implications for the expression of LTP. Neuron 15:427-434.

Iwasato T, Erzurumlu RS, Huerto PT, Sasaoka T, Ulupinar E, Tonegawa S (1997) NMDA receptor-dependent refinement of somatotopic maps. Neuron 19:1-20.

Kashiwagi K, Pahk AJ, Masuko T, Igarashi K, Williams K (1997) Block and 
modulation of N-methyl-D-aspartate receptors by polyamines and protons: role of amino acid residues in the transmembrane and pore forming regions of NR1 and NR2 subunits. Mol Pharmacol 52:701-713.

Killackey HP, Belford GR (1979) The formation of afferent patterns in the somatosensory cortex of the neonatal rat. J Comp Neurol 183:285-303.

Killackey HP, Belford G, Ryugo R, Ryugo DK (1976) Anomalous organization of thalamocortical projections consequent to vibrissae removal in the newborn rat and mouse. Brain Res 104:309-315.

Kim HC, Chung MY (1999) Voltage-dependent sodium and calcium currents in acutely isolated adult rat trigeminal root ganglion neurons. J Neurophysiol 81:1123-1134.

Kutsuwada T, Sakimura K, Manabe T, Takayama C, Katakura N, Kushiya E, Natsume R, Watanabe M, Inoue Y, Yagi T, Aizawa S, Arakawa M, Takahashi T, Nakamura Y, Mori H, Mishina M (1996) Impairment of suckling response, trigeminal neuronal pattern formation, and hippocampal LTD in NMDA receptor e2 subunit mutant mice. Neuron 16:333-344.

Lebedev MA, Nicolelis MA (2006) Brain-machine interfaces: past, present and future. Trends Neurosci 29:536-546.

Lee LJ, Lo F-S, Erzurumlu RS (2005) NMDA receptor-dependent regulation of axonal and dendritic branching. J Neurosci 25:2304-2311.

Li Y, Erzurumlu RS, Chen C, Jhaveri S, Tonegawa S (1994) Whisker-related neuronal patterns fail to develop in the brainstem trigeminal nuclei of NMDAR1 knockout mice. Cell 76:427-437.

Liao D, Hessler NA, Malinow R (1995) Activity of postsynaptic silent synapses during pairing-induced LTP in CA1 region of hippocampal slice. Nature 375:400-404.

Lo F-S, Erzurumlu RS (2001) Neonatal deafferentation does not alter membrane properties of developing trigeminal principal sensory nucleus neurons. J Neurophysiol 85:1088-1096.

Lo F-S, Erzurumlu RS (2002) L-Type calcium channel-mediated plateau potentials in barrelette cells of the principal trigeminal nucleus during structural plasticity. J Neurophysiol 88:794-801.

Lo F-S, Mize RR (2001) Properties of LTD and LTP of retinocollicular synaptic transmission in the developing rat superior colliculus. Eur J Neurosci 15:1421-1432.

Lo F-S, Guido W, Erzurumlu RS (1999) Electrophysiological properties and synaptic responses of cells in the whisker representation area of the postnatal rat trigeminal principal sensory nucleus. J Neurophysiol 82:2765-2775.

Lu W, Constantine-Paton M (2004) Eye opening rapidly induces synaptic potentiation and refinement. Neuron 43:237-249.

Lu W-Y, Man H-Y, Ju W, Trimble WS, MacDonald JF, Wang YT (2001) Activation of synaptic NMDA receptors induces membrane insertion of new AMPA receptors and LTP in cultured hippocampal neurons. Neuron 29:243-254.

Malenka RC, Bear MF (2004) LTP and LTD: an embarrassment of riches. Neuron 44:5 21.

Malinow R, Malenka RC (2002) AMPA receptor trafficking and synaptic plasticity. Annu Rev Neurosci 25:103-126.

Miller MW, Kuhn P (1997) Neonatal transection of the infraorbital nerve increases the expression of protein related to neuronal death in the principal sensory nucleus of the trigeminal nerve. Brain Res 796:233-244.
Miller MW, al-Ghoul WM, Murtaugh M (1991) Expression of ALZ-50 immunoreactivity in the developing principal sensory nucleus of the trigeminal nerve: effect of transecting the infraorbital nerve. Brain Res 560:132-138.

Minnery BS, Simon DJ (2003) Response properties of whisker-associated trigeminothalamic neurons in rat nucleus principalis. J Neurophysiol $89: 40-56$

Rudhard Y, Kneussel M, Nassar MA, Rast GF, Annala AJ, Chen PE, Tigaret CM, Dean I, Roes J, Gibb AJ, Hunt SP, Schoepfer R (2003) Absence of Whisker-related pattern formation in mice with NMDA receptors lacking coincidence detection properties and calcium signaling. J Neurosci 23:2323-2332.

Sakurada K, Masu M, Nakanishi S (1993) Alteration of Ca2+ permeability and sensitivity to $\mathrm{Mg} 2+$ and channel blocker by a single amino acid substitution in the N-methyl-D-aspartate receptor. J Biol Chem 268:410-415.

Scheetz AJ, Constantine-Paton M (1994) Modulation of NMDA receptor function: implications for vertebrate neural development. FASEB J 8:745-752.

Schneggenburger R, Ascher P (1997) Coupling of permeation and gating in an NMDA-channel pore mutant. Neuron 18:167-177.

Sheng M, Lee SH (2003) AMPA receptor trafficking and synaptic plasticity: major unanswered questions. Neurosci Res 46:127-134.

Shoykhet M, Shetty P, Minnery BS, Simons D (2003) Protracted development of responses to whisker deflection in rat trigeminal ganglion neurons. J Neurophysiol 90:1432-1437.

Single FN, Rozov A, Burnashev N, Zimmermann F, Hanley DF, Forrest D, Curan T, Jensen V, Hvalby O, Sprengel R, Seeburg PH (2000) Dysfunctions in mice by NMDA receptor point mutations NR1(N598Q) and NR1(N598R). J Neurosci 20:2558-2566.

Sugimoto T, Xiao C, Takeyama A, He Y-F, Takano-Yamamoto T, Ichikawa H (1999) Apoptotic cascade of neurons in the subcortical sensory relay nuclei following the neonatal infraorbital nerve transection. Brain Res 824:284-290.

Triller A, Choquet D (2005) Surface trafficking of receptors between synaptic and extrasynaptic membranes: and yet they do move! Trends Neurosci 28:133-139.

Waite PM, Li L, Ashwell KW (1992) Developmental and lesion induced cell death in the rat ventrobasal complex. NeuroReport 3:485-488.

Woolsey TA (1990) Peripheral alteration and somatosensory development. In: Development of Sensory Systems in Mammals (Coleman EJ, ed), pp 461-516. New York: Wiley.

Zhang LI, Tao HW, Poo M-M (2000) Visual input induces long-term potentiation of developing retinotectal synapses. Nat Neurosci 3:708-715.

Zheng X, Zhang L, Wang AP, Araneda RC, Lin Y, Zukin RS, Bennett MVL (1999) Mutation of structural determinants lining the N-methyl-Daspartate receptor channel differentially affects phencyclidine block and spermine potentiation and block. Neuroscience 93:125-134.

Zhou Q, Tao H-W, Poo M-M (2003) Reversal and stabilization of synaptic modifications in a developing visual system. Science 300:1953-1957. 